\title{
Kronik Böbrek Yetmezliği Hastalarında Renal ve Tiroid Fonksiyon Testlerinin Değerlendirilmesi
}

\section{Mustafa YÖNTEM1 (iD Birgül Gülşah ERBIL² ${ }^{2}$ Behiç Selman ERDOĞDU³}

${ }^{1}$ Necmettin Erbakan University, Faculty of Science, Department of Biotechnology, 42090, Meram, Konya, Turkey, (Sorumlu Yazar/Corresponding Author)

${ }^{2}$ Dumlupinar University, Institute of Graduate Education, Department of Biology, 43100, Kütahya, Turkey

${ }^{3}$ Necmettin Erbakan University, Faculty of Science, Department of Molecular Biology and Genetics, 42090, Meram, Konya, Turkey

\begin{tabular}{|c|c|}
\hline Makale Bilgileri & ÖZET \\
\hline $\begin{array}{l}\text { Makale Geçmişi } \\
\text { Geliş: } 15.09 .2020 \\
\text { Kabul: } 19.10 .2020 \\
\text { Yayın: } 31.12 .2020 \\
\text { Anahtar Kelimeler: } \\
\text { Kronik Böbrek } \\
\text { Yetmezliği, } \\
\text { Hemodiyaliz, } \\
\text { Tiroid fonksiyon } \\
\text { testleri. }\end{array}$ & 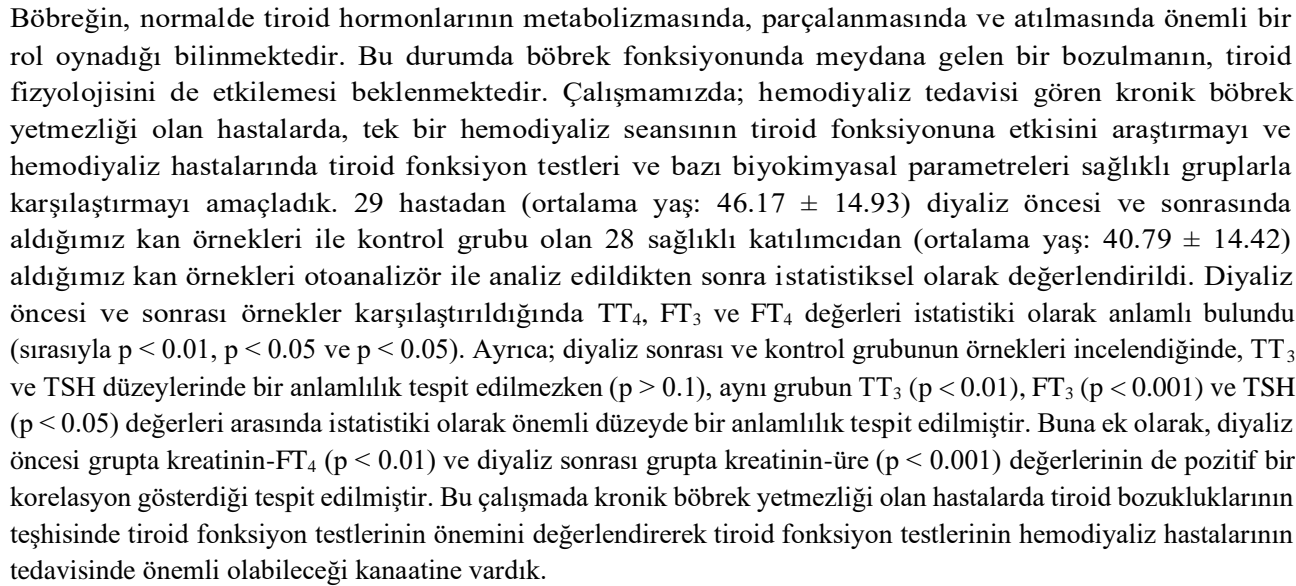 \\
\hline
\end{tabular}

Evaluation of Renal and Thyroid Function Tests in Chronic Renal Failure Patients

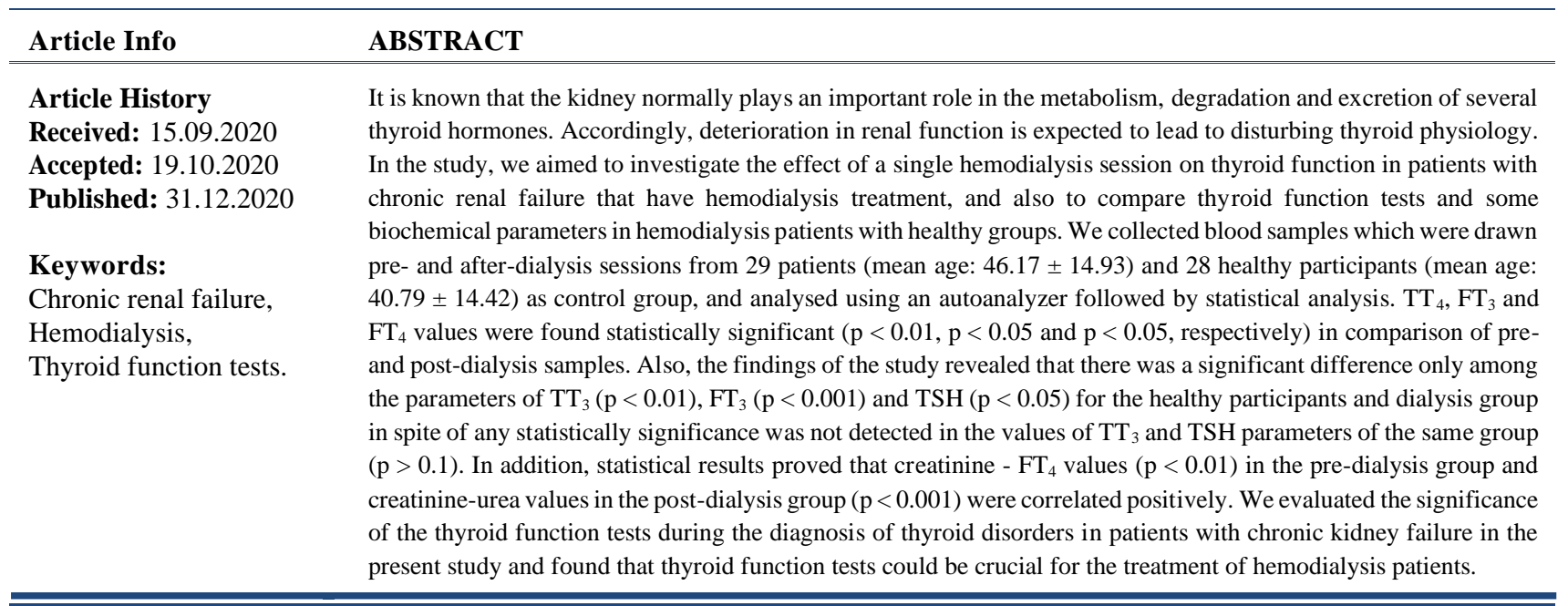

Atıf/Citation: Yontem, M.; Erbil, BG.; Erdogdu, BS. (2020). Evaluation of Renal and Thyroid Function Tests in Chronic Renal Failure Patients, Necmettin Erbakan Üniversitesi Fen ve Mühendislik Bilimleri Dergisi, 2(2), 52-57. 


\section{INTRODUCTION}

The relationship between kidney and thyroid function is a well-known phenomenon for many years [1]. Chronic renal failure (CRF) is characterized by the progressive and irreversible loss of nephrons. CRF has become an epidemic due to its increasing incidence and prevalence worldwide with adverse health outcomes and high costs [2,3]. A part of the metabolic wastes originated from various organ and/or system disorders are removed by hemodialysis procedure. The endocrine abnormalities are commonly observed in CRF patients. Kidneys play an important role in the metabolism, degradation and excretion of thyroid hormones. Thyroid hormones are very crucial in the CRF patients by reason of their influence on the homeostasis of body fluids, vascular resistance and blood pressure [4,5]. Renal function of the patients with chronic kidney disease is affected by various reasons such as decreased thyroid hormone concentration in the circulation, damaged peripheral hormone metabolism, deficient binding to carrier proteins, reduced thyroid hormone content in the tissue and increased iodine deposition in the thyroid glands [6,7]. Chronic renal disease affects the hypothalamus-pituitary-thyroid triangle and the peripheral metabolism of thyroid hormones. Even though most hemodialysis patients are euthyroid [8], subclinical hyperthyroidism and reduced $\mathrm{T}_{3}$ levels are the most common findings in these patients [9]. And, possible loss of hormone via hemodialysis fluid and heparin used for hemodilution during the procedure could affect serum lipids and thyroid hormones. The aim of this study is to compare the urea, creatinine, and thyroid function indicators and reveal the significance of these parameters in hemodialysis patients.

\section{MATERIAL AND METHODS}

29 hemodialysis patients who were followed and treated in the Hemodialysis Unit of Eskişehir State Hospital, Eskişehir, Turkey and 28 healthy individuals were included in the study. This study was performed within the guidelines of the Helsinki Declaration. All participants were informed about the objective of this research. Patient group was checked up before the blood samples were taken whether the existence of any disorder except CRF or not. Cases with any additional disorder to CRF were not included in the study group. 10-12 $\mathrm{ml}$ of blood samples were drawn into vacutainer tubes from arm vein with avoiding any formation of stasis or hemolysis and centrifuged at $4000 \mathrm{rpm}$ for 5 minutes. The parameters of urea, creatinine, total $\mathrm{T}_{3}\left(\mathrm{TT}_{3}\right)$, total $\mathrm{T}_{4}\left(\mathrm{TT}_{4}\right)$, free $\mathrm{T}_{3}\left(\mathrm{FT}_{3}\right)$, free $\mathrm{T}_{4}\left(\mathrm{FT}_{4}\right)$ and thyroid stimulating hormone (TSH) were analyzed in Roche Hitachi 7180 clinical autoanalyzer (Hitachi, Tokyo, Japan; reagents from Roche Diagnostics, Mannheim, Germany) by using commercial kits of the same brand. All our analyses from the samples obtained were carried out immediately.

Any differences in parameters between control group and dialysis groups were tested for significance by two-tailed unpaired t-test. And, paired t-test was used for any differences in parameters between patients before dialysis (BD) and after dialysis (AD) groups. $\mathrm{p}<0.05$ was considered to be statistically significant. Also, Pearson's correlation analysis was achieved measure the strength of a linear association between parameters. The statistical analysis of our findings was carried out by using "GraphPad Prizm 3.03" program.

\section{RESULTS}

The study group consisted of 14 female $(43.64 \pm 13.77)$ and 15 male $(48.53 \pm 16.05)$ patients and the control group consisted of 14 healthy women $(35 \pm 10.57)$ and 14 healthy men $(46.57 \pm 15.75)$ who have normal kidney function tests, have no known disease, do not smoke and use alcohol, and are suitable for the same age average (Table 1). The results of analyzed blood samples which were taken before and after the dialysis session were compared with the control group (Table 2 and Table 3).

Statistical results of pre- and post-dialysis data of the patient group reveals that $\mathrm{TT}_{4}, \mathrm{FT}_{3}$ and $\mathrm{FT}_{4}$ values were significantly increased $(\mathrm{p}<0.0001)$ after dialysis session in comparison of pre-dialysis samples. 
Table 1. Demographic distribution of the cases.

\begin{tabular}{lcccc} 
& \multicolumn{2}{c}{ Hemodialysis Group } & \multicolumn{2}{c}{ Control Group } \\
& Men & Women & Men & Women \\
\hline $\mathbf{n}^{*}$ (Population) & 15 & 14 & 14 & 14 \\
Age Average & $48.53 \pm 16.05$ & $43.64 \pm 13.77$ & $46.57 \pm 15.75$ & $35 \pm 10.57$ \\
$\mathbf{2}$ Age average & \multicolumn{2}{c}{$46.17 \pm 14.93$} & $40.79 \pm 14.42$ \\
Number of years on dialysis & $7.57 \pm 4.95$ & $7.28 \pm 4.51$ & & \\
Number of days of dialysis per week & $3 \pm 0.65$ & $2.86 \pm 0.36$ & & \\
\hline $\mathbf{n}^{*}$ : Number of cases participating in the study & \multicolumn{4}{r}{}
\end{tabular}

$\mathrm{n}^{*}$ : Number of cases participating in the study.

Table 2. The comparison of kidney function results in the study and control groups.

\begin{tabular}{ccccc} 
Parameters $^{1}$ & Group $^{2}$ & Mean \pm SD $^{3}$ & $\mathbf{t}^{4}$ & $\mathbf{p}^{5}$ \\
& CG & $28.44 \pm 6.22$ & 17.39 & $\mathrm{p}<0.001^{* * *}$ \\
Urea & BD & $124.6 \pm 28.59$ & & \\
$(\mathrm{mg} / \mathrm{dL})$ & CG & $28.44 \pm 6.22$ & 5.02 & $\mathrm{p}<0.0001^{* * * *}$ \\
& AD & $41.88 \pm 12.77$ & & \\
& BD & $124.6 \pm 28.59$ & 21.83 & $\mathrm{p}<0.0001^{* * * *}$ \\
& AD & $41.88 \pm 12.77$ & & \\
& CG & $0.84 \pm 0.21$ & 14.64 & $\mathrm{p}<0.0001^{* * * *}$ \\
Creatinine & BD & $7.6 \pm 2.45$ & & \\
$(\mathrm{mg} / \mathrm{dL})$ & CG & $0.84 \pm 0.21$ & 12.98 & $\mathrm{p}<0.0001^{* * * *}$ \\
& AD & $3.01 \pm 0.86$ & & \\
& BD & $7.6 \pm 2.45$ & 11.04 & $\mathrm{p}<0.0001^{* * * *}$ \\
\hline
\end{tabular}

${ }^{1}$ : Biochemical parameters; ${ }^{2}$ : Groups; AD: after dialysis, BD: before dialysis, CG: control group; ${ }^{3}:$ mean and standard deviation of results; ${ }^{4}: \mathrm{t}$ test values; ${ }^{5}$ : p significance values. $*$ : borderline, $* *$ normal, $* * *$ high, $* * * *$ very high

Besides, any significance was not detected on $\mathrm{TT}_{3}$ and TSH levels of the same group $(\mathrm{p}>0.1)$. Contrary to this, $\mathrm{TT}_{3}, \mathrm{FT}_{3}$ and TSH levels were statistically significant ( $\mathrm{p}<0.01,0.0001$ and $\mathrm{p}<0.05$; respectively) in comparison of post-dialysis group with healthy volunteers. $\mathrm{TT}_{3}, \mathrm{TT}_{4}, \mathrm{FT}_{3}$ and $\mathrm{FT}_{4}$ results of pre-dialysis samples of the patient group were found statistically significant $(\mathrm{p}<0.01, \mathrm{p}<0.001, \mathrm{p}<0.0001$ and $\mathrm{p}<0.001$; respectively) when they compared with healthy volunteers. Moreover, creatinine - $\mathrm{FT}_{4}$ values of pre-dialysis samples and creatinine - urea values of the post-dialysis samples of patient group were positively correlated ( $\mathrm{p}$ $<0.01$ and $\mathrm{p}<0.001$, respectively) (Table 2 and Table 3 ).

As seen on Table 2, statistically significance was found on the Urea and Creatinine parameters when preand post-dialysis values of patients compared with the control group $(\mathrm{p}<0.001$; $\mathrm{p}<0.0001 \mathrm{p}<0.0001$; $\mathrm{p}<$ 0.0001 ; respectively).

In our correlation analysis between obtained results of all three groups, a statistically positive correlation was found between urea-TSH, creatinine-FT 3 and creatinine-FT 4 values in our control group $(\mathrm{p}<0.01$ and $\mathrm{p}<$ $0.001, r=-0.445$ and $r=0.461, r=0.579)$. In our pre-dialysis group, there was a statistically positive correlation between creatinine-FT3 ( $\mathrm{p}<0.04$ and $\mathrm{r}=-0.382)$. Also, a positive correlation between creatinine-urea values in our post-dialysis group $(\mathrm{p}<0.0001 \mathrm{r}=0.0713)$ has been identified.

\section{DISCUSSION}

Various studies have demonstrated that $\mathrm{TT}_{3}, \mathrm{TT}_{4}$ and TSH levels decrease in both CRF [10-13] and hemodialysis patients similarly [14,15]. Most hemodialysis patients are considered euthyroid according to common opinion, hence, hypothyroidism is rarely seen in these patients [16]. Hemodialysis is associated with the change in the concentration of thyroid hormones in the circulation. The decrease of $\mathrm{TT}_{3}$ and $\mathrm{FT}_{3}$ 
Table 3. The comparison of thyroid function results in the study and control groups.

\begin{tabular}{|c|c|c|c|c|}
\hline Parameters ${ }^{1}$ & Group $^{2}$ & Mean $\pm \mathbf{S D}^{3}$ & $\mathbf{t}^{4}$ & $\mathbf{p}^{5}$ \\
\hline \multirow{6}{*}{$\begin{array}{c}\mathbf{T T}_{\mathbf{3}} \\
(\mathrm{ng} / \mathrm{mL})\end{array}$} & $\overline{C G}$ & $1.18 \pm 0.21$ & \multirow{2}{*}{2.99} & \multirow{2}{*}{$\mathrm{p}<0.01 * *$} \\
\hline & $\mathrm{BD}$ & $0.99 \pm 0.25$ & & \\
\hline & $\mathrm{CG}$ & $1.18 \pm 0.21$ & \multirow{2}{*}{3.16} & \multirow{2}{*}{$\mathrm{p}<0.01 * *$} \\
\hline & $\mathrm{AD}$ & $0.99 \pm 0.22$ & & \\
\hline & $\mathrm{BD}$ & $0.99 \pm 0.25$ & \multirow{2}{*}{0.077} & \multirow{2}{*}{$\mathrm{p}>0.1$} \\
\hline & $\mathrm{AD}$ & $0.99 \pm 0.22$ & & \\
\hline \multirow{6}{*}{$\begin{array}{c}\mathbf{T T}_{4} \\
(\mu \mathrm{g} / \mathrm{dL})\end{array}$} & $\mathrm{CG}$ & $8.35 \pm 1.57$ & \multirow{2}{*}{5.22} & \multirow{2}{*}{$\mathrm{p}<0.001 * * *$} \\
\hline & $\mathrm{BD}$ & $6.13 \pm 1.63$ & & \\
\hline & $\mathrm{CG}$ & $8.35 \pm 1.57$ & \multirow{2}{*}{0.40} & \multirow{2}{*}{$\mathrm{p}>0.1$} \\
\hline & $\mathrm{AD}$ & $8.15 \pm 2.23$ & & \\
\hline & $\mathrm{BD}$ & $6.13 \pm 1.63$ & \multirow{2}{*}{8.83} & \multirow{2}{*}{$\mathrm{p}<0.0001 * * * *$} \\
\hline & $\mathrm{AD}$ & $8.15 \pm 2.23$ & & \\
\hline \multirow{6}{*}{$\begin{array}{c}\mathbf{F T}_{3} \\
(\mathrm{pg} / \mathrm{mL})\end{array}$} & $\mathrm{CG}$ & $3.17 \pm 0.58$ & \multirow{2}{*}{7.36} & \multirow{2}{*}{$\mathrm{p}<0.0001 * * * *$} \\
\hline & $\mathrm{BD}$ & $2.23 \pm 0.36$ & & \\
\hline & $\mathrm{CG}$ & $3.17 \pm 0.58$ & \multirow{2}{*}{5.09} & \multirow{2}{*}{$\mathrm{p}<0.0001 * * * *$} \\
\hline & $\mathrm{AD}$ & $2.50 \pm 0.39$ & & \\
\hline & $\mathrm{BD}$ & $2.23 \pm 0.36$ & \multirow{2}{*}{4.95} & \multirow{2}{*}{$\mathrm{p}<0.0001 * * * *$} \\
\hline & $\mathrm{AD}$ & $2.50 \pm 0.39$ & & \\
\hline \multirow{6}{*}{$\begin{array}{c}\mathbf{F T}_{4} \\
(\mathrm{ng} / \mathrm{mL})\end{array}$} & $\mathrm{CG}$ & $1.24 \pm 0.20$ & \multirow{2}{*}{3.29} & \multirow{2}{*}{$\mathrm{p}<0.001 * * *$} \\
\hline & $\mathrm{BD}$ & $1.04 \pm 0.26$ & & \\
\hline & $\mathrm{CG}$ & $1.24 \pm 0.20$ & \multirow{2}{*}{0.66} & \multirow{2}{*}{$\mathrm{p}>0.1$} \\
\hline & $\mathrm{AD}$ & $1.20 \pm 0.27$ & & \\
\hline & $\mathrm{BD}$ & $1.04 \pm 0.26$ & \multirow{2}{*}{8.46} & \multirow{2}{*}{$\mathrm{p}<0.0001 * * * *$} \\
\hline & $\mathrm{AD}$ & $1.20 \pm 0.27$ & & \\
\hline \multirow{6}{*}{$\begin{array}{c}\text { TSH } \\
(\mathrm{IU} / \mathrm{mL})\end{array}$} & $\mathrm{CG}$ & $2.67 \pm 1.13$ & \multirow{2}{*}{1.29} & \multirow{2}{*}{$\mathrm{p}>0.1$} \\
\hline & $\mathrm{BD}$ & $2.20 \pm 1.55$ & & \\
\hline & $\mathrm{CG}$ & $2.67 \pm 1.13$ & & $\mathrm{n}<0,05 *$ \\
\hline & $\mathrm{AD}$ & $2.06 \pm 1.38$ & 1.81 & $\mathrm{p}<0.05^{*}$ \\
\hline & $\mathrm{BD}$ & $2.20 \pm 1.55$ & 162 & $\mathrm{n}>01$ \\
\hline & $\mathrm{AD}$ & $2.06 \pm 1.38$ & 1.62 & $\mathrm{p}>0.1$ \\
\hline
\end{tabular}

1: Biochemical parameters; ${ }^{2}$ : Groups; AD: after dialysis, BD: before dialysis, CG: control group; ${ }^{3}:$ mean and standard deviation of results; ${ }^{4}$ : test values; ${ }^{5}$ : p significance values. $*$ : borderline, $* *$ normal, $* * *$ high, $* * * *$ very high

concentrations in blood can cause a number of serious disorders such as systemic acidosis, dialysis, endothelial damage, cardiac dysfunction and inflammation [17]. In our study, $\mathrm{TT}_{3}, \mathrm{TT}_{4}, \mathrm{FT}_{3}$ and $\mathrm{FT}_{4}$ results of pre-dialysis samples of the patient group were lower and statistically significant compared to the healthy individuals.

Concentrations of $\mathrm{TT}_{3}, \mathrm{TT}_{4}, \mathrm{FT}_{3}$ and $\mathrm{FT}_{4}$ are usually normal in CRF patients, however, they might be lower than normal in some cases. The decrease in $\mathrm{T}_{3}$ concentration due to decline in peripheral synthesis of $\mathrm{T}_{3}$ from $\mathrm{T}_{4}$ is the most common thyroid change in hemodialysis patients.

Chronic metabolic acidosis associated with CRF may contribute to the emergence of this decline. In addition to this, drugs used for anti-coagulation during hemodialysis have been reported to affect thyroid function test results $[17,18]$.

In this study, we found that $\mathrm{TT}_{4}$ levels were raised significantly in post-dialysis group while the difference between pre- and post-dialysis values of $\mathrm{TT}_{3}$ was not significant. The difference in the levels of $\mathrm{TT}_{3}$ between pre-dialysis and healthy individuals was also statistically significant. When levels of post-dialysis samples and healthy individuals were compared, the difference according to pre-dialysis results was smaller but meaningful statistically. While $\mathrm{TT}_{4}$ levels of healthy individuals and pre-dialysis were statistically very significant, any 
significance was not detected in the post-dialysis group.

Many researchers have indicated that CRF patients exhibit normal TSH levels and classified them as euthyroid $[8,19,20]$. Conversely, in one study, patients were classified as subclinical hypothyroidism due to minor changes in TSH levels [21]. In our study, any statistical significance was not found even though TSH levels of patient group were lower than the healthy individuals.

Plasma $\mathrm{FT}_{3}$ levels are low in patients with end-stage renal disease. Besides, it has been stated that $\mathrm{FT}_{3}$ ranges acutely and reversibly during the inflammatory process triggered by various infections that may occur in individuals with chronic renal disease [17-19]. The $\mathrm{FT}_{3}$ values in our study are consistent with these findings. In comparison of the healthy individuals, both the pre and after dialysis groups were statistically significant. While $\mathrm{FT}_{4}$ values of our control group compared with pre- and post-dialysis results were not statistically significant, whereas $\mathrm{FT}_{4}$ results of the pre- and post-dialysis groups were significant.

\section{CONCLUSION}

As a result; from a clinical point of view, testing for thyroid function is usually sufficient in patients with kidney disease, but the effects of hypothyroidism and hyperthyroidism on renal function should be considered for the removal of the diagnostic errors. Since the drugs used in the treatment of thyroid and kidney diseases may lead to changes in the pathophysiology of these organs, the differences that may be encountered in thyroid function tests in acute or chronic renal diseases should also be considered.

\section{REFERENCES}

[1] A.I. Katz, D.S. Emmanouel, M.D. Lindheimer, Thyroid hormone and the kidney, Nephron. 15 (1975) 223-249.

[2] G. Süleymanlar, Kronik böbrek hastalı̆̆ı ve yetmezliği: tanımı, evreleri ve epidemiyolojisi, Türkiye Klinikleri Dahili Tip Bilimleri Dergisi. 3 (2007) 1-7.

[3] A.S. Levey, J. Coresh, E. Balk, A.T. Kausz, A. Levin, M.W. Steffes, R.J. Hogg, R.D. Perrone, J. Lau, G. Eknoyan, National Kidney Foundation practice guidelines for chronic kidney disease: evaluation, classification, and stratification, Annals of Internal Medicine. 139 (2003) 137-147.

[4] W.J. Kalk, J.E. Morley, C.H. Gold, A. Meyers, Thyroid function tests in patients on regular hemodialysis, Nephron. 25 (1980) 173-178.

[5] M.C. Pagliacci, G. Pelicci, F. Grignani, C. Giammartino, L. Fedeli, C. Carobi, U. Buoncristiani, I. Nicoletti, Thyroid function tests in patients undergoing maintenance dialysis: characterization of the 'low-T4 syndrome'in subjects on regular hemodialysis and continuous ambulatory peritoneal dialysis, Nephron. 46 (1987) 225-230.

[6] G. Lippi, M. Montagnana, G. Targher, G.L. Salvagno, G.C. Guidi, Relationship between thyroid status and renal function in a general population of unselected outpatients, Clinical Biochemistry. 41 (2008) $625-627$.

[7] G. Rajeev, W.D.S.C. Rayappa, R. Vijayalakshmi, M. Swathi, S. Kumar, Evaluation of thyroid hormone levels in chronic kidney disease patients, Saudi Journal of Kidney Diseases and Transplantation. 26 (2015) 90.

[8] M.W. Szkudlinski, V. Fremont, C. Ronin, B.D. Weintraub, Thyroid-stimulating hormone and thyroidstimulating hormone receptor structure-function relationships, Physiological Reviews. 82 (2002) $473-$ 502.

[9] G. Basu, A. Mohapatra, Interactions between thyroid disorders and kidney disease, Indian Journal of Endocrinology and Metabolism. 16 (2012) 204.

[10] J. Punekar, A.A. Singh, M.K. Malav, Study of thyroid function in patients with chronic kidney disease, Int J Health Sci Res. 7 (2017) 68-72. 
[11] P.B. V Vivek, S. Kirubakaran, K. Elavarasan, S. Natarajan, A Prospective Study on the Evaluation of Thyroid Function Status in Patients with Chronic Kidney Disease, Journal of Medical Science and Clinical Research. 5 (2017) 28007-28014. doi:https://dx.doi.org/10.18535/jmscr/v5i9.107.

[12] V. V Deokar, S.S. Patil, K. Babu, J. Patel, Evaluation of thyroid function status in patients with chronic kidney disease, Journal of Critical Reviews. 7 (2020) 535-538.

[13] P. Iglesias, J.J. Díez, Thyroid dysfunction and kidney disease, European Journal of Endocrinology. 160 (2009) 503-515.

[14] J. Horacek, S.D. Sulkova, M. Kubisova, R. Safránek, E. Malírova, M. Kalousová, I. Svilias, J. Malý, L. Sobotka, P. Zák, Thyroid hormone abnormalities in hemodialyzed patients: low triiodothyronine as well as high reverse triiodothyronine are associated with increased mortality, Physiological Research. 61 (2012) 495 .

[15] S.E.S. Farag, Functional and Morphological Thyroid Disorders in Hemodialysis Patients, J Thyroid Disord Ther. 2 (2013) 2-5.

[16] S. Jusufovic, E. Hodzic, Functional thyroid disorders are more common in patients on chronic hemodialysis compared with the general population, Materia Socio-Medica. 23 (2011) 206.

[17] E.O. Kim, I.S. Lee, Y.A. Choi, S.J. Lee, Y.K. Chang, H.E. Yoon, Y.S. Jang, J.M. Lee, H.S. Kim, C.W. Yang, Unresolved subclinical hypothyroidism is independently associated with progression of chronic kidney disease, International Journal of Medical Sciences. 11 (2014) 52.

[18] S. Sakurai, Y. Hara, S. Miura, M. Urabe, K. Inoue, T. Tanikawa, M. Yanagisawa, M. Iitaka, J.U.N. Ishii, Thyroid functions before and after maintenance hemodialysis in patients with chronic renal failure, Endocrinologia Japonica. 35 (1988) 865-876.

[19] K. Yonemura, T. Nakajima, T. Suzuki, S. Ando, R. Genma, H. Nakamura, A. Hishida, Low free thyroxine concentratios and deficient nocturnal surge of thyroid-stimulating hormone in haemodialysed patients compared with undialysed patients, Nephrology Dialysis Transplantation. 15 (2000) 668-672.

[20] J. Malyszko, J. Malyszko, S. Wolczynski, M. Mysliwiec, Adiponectin, leptin and thyroid hormones in patients with chronic renal failure and on renal replacement therapy: are they related?, Nephrology Dialysis Transplantation. 21 (2006) 145-152.

[21] M. Tarakçıŏglu, E. Algün, R. Şekeroğlu, S. Alıcı, S. Topal, İ. Meral, Hemodiyaliz Hastalarında Tiroid Hormon Düzeyleri ve Bir Hemodiyaliz Seansının Bu Değerlere Etkisi, Van Tıp Dergisi. 4 (n.d.) 201204. 